\title{
THE EFFECT OF STRATEGY TRAINING ON UNDERGRADUATE STUDENTS' FREQUENCY OF STRATEGY USE AND PERCEPTIONS OF CHALLENGES FACED IN WRITING PROCESS ${ }^{1}$
}

\author{
Çilem AYDOĞDU²
}

Geliş: 08.06.2021 / Kabul: 27.07.2021

DOI: $10.29029 /$ busbed.949459

\section{Abstract}

The aim of this study is to determine the difficulties that students face in writing process, to investigate the effect of writing strategies training on their perception towards writing process, and on the students' use of the writing strategies. For these purposes, a mixed-method research design was used. Participants consisted of 78 undergraduate students studying in the English Language and Literature Department at Bingöl University. Control group consisted of 42 participants where as there were 37 participants in experimental group. 24 students in the experimental group were interviewed through two openended questions. The findings obtained through the interview revealed that students experienced problems in the writing process in terms of presenting ideas, organizing these ideas, obeying the grammar rules, managing the time, choosing appropriate words and using proper punctuation marks. It was also revealed that almost all participants' strategy use increased after strategy instruction at prewriting, during writing and post writing stages and the qualitative data results indicated that participants were in favor of strategy use for each stage of the writing process.

Keywords: Writing strategies training, perception, attitude, writing difficulties.

\footnotetext{
${ }^{1}$ Bu çalışma Çilem AYDOĞDU'nun "Yazma Stratejileri Eğitiminin İngilizceyi Yabancı Dil Olarak Öğrenen Türk Öğrencilerin Akademik Yazma Performanslarına Etkisi” adlı doktora çalışmasından yararlanılarak oluşturulmuştur.

${ }^{2}$ Dr. Öğr. Üyesi, Bingöl Üniversitesi Yabanci Diller Yüksekokulu, cbozkir@bingol.edu.tr, ORCID: https://orcid.org/0000-0001-5991-9589.
} 


\section{STRATEJI Ë̆İTIMİNIN LISANS ÖĞRENCİLERINİN STRATEJI KULLANIM SIKLIĞINA VE YAZMA SÜRECINDE KARŞILAŞTIĞI ZORLUKLARA DAIR ALGILARINA ETKISİ}

\section{$\ddot{O} z$}

$\mathrm{Bu}$ araştırmanın amacı, öğrencilerin yazma sürecinde karşılaştıkları zorlukları belirlemek, yazma stratejileri eğitiminin yazma sürecine yönelik algıları üzerindeki etkisini ve yazma stratejileri kullanımına etkisini incelemektir. Bu amaçlar için karma yöntem araştırma tasarımı kullanılmıştır. Araştırmanın katılımcıları Bingöl Üniversitesi İngiliz Dili ve Edebiyatı Bölümü'nde ögrenim gören 78 lisans ögrencisinden oluşmuştur. Bu katılımcllar 42 kontrol grubu ve 37 deney grubu olmak üzere ikiye ayrlld. Deney grubundaki 24 ögrenciyle iki açık uçlu soruyla görüşülmüştür. Görüşme sonucunda elde edilen bulgular, öğrencilerin yazma sürecinde fikir sunma, bu fikirleri düzenleme, dilbilgisi kurallarına uyma, zamanı yönetme, uygun kelime seçme ve noktalama işaretlerini doğru kullanma açısından sorun yaşadıkların ortaya koymuştur. Ayrıca, hemen hemen tüm katılımcıların strateji eğitiminden sonra strateji kullanımının yazma öncesi, yazma esnası ve yazma sonrası aşamalarda arttı̆̆ını ve nitel veri sonuçlarının katılımcıların yazma sürecinin her aşamasında strateji kullanımından yana olduklarını ortaya çıkarmıştır.

Zorluklarl.

Anahtar kelimeler: Yazma Staratejileri Eğitimi, Algı,Tutum, Yazma

\section{Introduction}

It has been long observed that the individuals have differences in their level of mastering a foreign or second language though they are exposed to the same foreign language education (Dörnyei, 2005). In this respect, the term "individuality" has begun to gain popularity among second language and foreign language studies (Cohen \& Dörnyei, 2002; Dörneyi, 2005; Oxford, 1990). Dörneyi (2005) highlights the importance of IDs (individual differences) identifying them as the most consistent predictors of second language (L2) learning success. Many researchers aiming to find the reason for some learners' being more successful at learning a foreign language have concluded that various learner differences are predictors of foreign language achievement (Dörnyei, 2005; Oxford, 1990). Due to its being regarded as a determining predictor of foreign language success, IDs have been studied extensively, and accordingly have been classified into different subcategories. Mainly, different components consisting IDs are defined as sex (Young \& Oxford, 1997) aptitude (Svaille- 
Troike, 2006) age (Long, 1990) motivation (Gardner, 1985) personality (Snow, Corno \& Jackson, 1996), learning styles (Cornett, 1983) and language learning strategies (O'Malley \& Chamot, 1990; Oxford, 1990). As aformentioned, one of the components of individual differences is "language learning strategy". It has taken so much attention in the SLA research area that Ellis (2004) defined its role stating "learning strategies have proved to be a gold mine to which many researchers have rushed." (p.546). Additionally, language learning strategies have been shown as among the most prominent factors contributing to the achievement of second language learning (Alias, Manan, Yusof, \& Pandian, 2012). Several studies have shown that more successful learners use strategies more frequently in the process of foreign language learning (Dörnyei, 2005). Furthermore, the use of language learning strategies have been regarded as effective factors in the development of specific domains of language; particularly, its crucial role in the development of the writing skill is revealed by many recent studies (Alhaysony, 2017; Nasihah \& Cahnoyo, 2017).

In universities, the obligatory academic writing course is mostly given to the students majoring in English departments. However, most of the practitioners complain about the difficulty of the writing process and the failure they experience. Addressing the complex nature of writing, Pasand (2013) describes writing as a set of involvements such as "development of an idea, the capture of mental representations of knowledge, of experience with subjects, accuracy of the grammatical patterns and lexico-grammatical structures" (p. 75). The concern regarding the complexity of writing skill is not different within the ESL contexts. Thus, the failure in writing skill and the challenges in writing process have urged researchers to study this specific domain of language.

In the late 1970s, serious research on how to teach writing in foreign language began to take concern, but the focus was on the accuracy of the final product. That is, one of the earliest approaches to writing is product-oriented approach in which grammatical structures and accuracy in terms of mechanic aspects of a completed text are emphasized. However, the validity of a productbased approach to writing was not beyond argument. According to researchers such as Zamel (1987) and Raimes (1985), focusing on the accuracy rather than the fluency hindered and unrated the creativity of the writing process. In other words, students were not involved in generating ideas, but they were producing mechanically good writings. The argument put forward by Zamel (1987) urges practitioners of writing skill to explore new options for teaching writing by giving more emphasis on the process of writing not the product. According to Allodwan 
and Ibnian (2014), the learners' involvement in the language learning process is more prominent through the process approach, now the learners are not seen as mere responders. According to Onozawa (2010), what makes process writing influential is not clear. However, Reid (2001) goes a step further explaining the reason as the existed methods' not meeting the demands and needs of the writers.

With these arguments, process-oriented writing classes have gained favor since the 1980s and led learners to generate and share their ideas in the process of writing. Zen (2005, p.194) summarizes the benefits of process approach to writing stating that "fluency was emphasized over the accuracy, and teaching effective strategies at each stage of the writing process became an important component of a writing class." Zen (2005) also points out that process-oriented writing instruction has given rise to several terms such as stages of writing, peer and teacher feedback, collaboration among students, use of affective strategies in the writing process. That is, the efforts are now in the process of the writing in which stages of writing have a crucial role. This issue then has brought researchers' attention to the steps of writing which are listed in different ways by various researchers; therefore, it has caused an ambiguity among researchers (Arndt, 1987; Wenden, 1991). However, the typical stages are prewriting, whilewriting, revising and editing. That is, before handling the final product, there are some stages to follow through which the individuals go. Process approach to writing does not only focus on steps of writing consisting of planning, drafting, revising and editing. At the same time, it involves the use of proper writing strategies for each step to improve the writing skill (Dujsik, 2008). In this regard, Bai (2016) highlights the relationship between process approach to writing and writing strategies stating "the term used in literature to refer studies of L1 writing strategies is writing process research; thus, the research of writing strategies has been part of research on process-oriented writing" (p.34).

The significance of use of writing strategies has been highlighted by a great body of research findings revealing a difference between good and poor writers in terms of their strategy use and it has been shown that the use of writing strategies by good writers is much more compared to poorer ones (Alkuabadi, 2014; Manounchery, Farengi, Fatemi \& Qavikeft, 2014). In fact, over the last three decades, there has been numerous studies related to the language learning strategies (Chu, Lin, Tsai \& Wang, 2015; Griffiths, 2008; O’ Malley\& Chamot, 1990). Thus, a great body of definitions have been put forward by different researchers; one of the common definitions for language learning strategies is that of O'Malley, Chamot, Manzare and Russo (1985) who define language learning 
strategies as "operations or steps used by a learner that will facilitate the acquisition, storage, retrieval or the use of information" (p.23). In addition to the explosion in definitions, LLSs also have received numerous classifications by different researchers (O 'Malley et al.,1985; Rubin, 1987; Oxford, 1990). While Rubin (1987) categorizes LLSs into three types as; learning strategies, communication strategies, and social strategies, O' Malley's (1985) classification of LLSs is in three major subcategories which are metacognitive, cognitive and socio-affective strategies. Oxford classifies it into two main types as direct (memory, cognitive and compensation strategies) and Indirect strategies (metacognitive, affective and social strategies).

The review of the relevant literature also suggests an explicit strategy instruction in the process of writing for the improvement in writing skills (Mohammadi, Birjandi \& Meftoon, 2015; O’Maley, 1985). Brown (2006) supports strategy instruction stating "as we seek to make the language classroom an effective milieu for learning, it has become increasingly apparent that teaching learners how to learn is crucial." (p.140). That is, to make learners more autonomous depends, to some extent, on the facilitation of teaching to learn. Regarding the difficulty of writing skill, Han and Hiver (2018) define this process as a "complex, time-consuming activity which requires concentration, effort, and persistence" (p.44). The importance of writing strategies on the solution of many difficulties faced in writing process is proposed as one of the prominent factors (Leki, 1995). The studies refer to the necessity of incorporation writing strategies into foreign language writing instruction. With the aid of strategy training, the dependence of learners to the teachers might decrease and accordingly learners will take more responsibility for their learning process. Thus, as relevant literature shows, writing skills might be improved in quality through the use of writing strategies.

\subsection{Research Questions}

The purpose of this study is to identify the writing strategies (WSs) sused by EFL learners via the Writing Strategy Questionnaire (WSQ) developed by Petric and Czarl (2003). Also, a semi-structured interview was developed and an experimental design was adopted including a writing strategy instruction to the experimental group. Mainly, this study aims to find answers to the following research questions;

1. Are there any differences in the frequency of use of writing strategies after writing 
strategy instruction between control and experimental groups?

2. What are the challenges do students in English Language and Literature department encounter in the process of writing?

3. What are the perceptions and attitudes of the students in the experimental group towards the use of writing strategies in before writing, when writing and after writing stages of the writing process?

\section{Methodology}

The current study is based on a mixed-methods research design. Since the main aim of the research was to reveal the effectiveness of WSs training on students' writing performances, experimental approach was adopted for the design of the study. Ross and Morisson (2003) define experimental design as "the experimenter's interest in the effect of environmental change, referred to as "treatments," demanded designs using standardized procedures to hold all conditions constant except the independent (experimental) variable." (p.1021).

As for quantitative data, a writing strategy questionnaire developed by Petric and Czarl (2003) was used. The students in both groups were given questionnaire at the beginning and end of the study. The qualitative side of the study consisted of a semi-structured interview. That is, both qualitative and quantitative data collection instruments were sequentially used.

\subsection{Participants}

The participants :were students in the first year of the English Language and Literature department at Bingöl University. The main reason for choosing this sample was the first year writing course curriculum as it was concerned with writing skills and was parallel in content to the planned study.

Some of the students were required to be excluded out of the study as they were absent from answering the questionnaire either in the pre-test questionnaire or post-test questionnaire. The number of participants was shown in Table 1.

Table 1. The Number of the Participants from the Experimental and Control Group who Completed Pre-test ad Post-test Questionnaires

\begin{tabular}{lcc}
\hline Groups & Pre-test & Post-test \\
\hline Control & 37 & 42 \\
Experimental & 43 & 37 \\
\hline
\end{tabular}


In addition to these participants, 24 students selected from experimental group were interviewed at the end of the study. The selection of the participants was according to the marking to maintain variety as follows: 5 participants with a mark of 80 or over, 5 participants with a mark of $70-80,5$ for $60-70,5$ for $60-50$, 4 for 50 or below.

\subsection{Data Collection Instruments}

For the purposes of the current study, two data collection tools were utilized. The instruments adopted were writing a writing strategy questionnaire developed by Petric and Czarl (2003), and a semi-structured interview. The questionnaire consists of two main parts. While the two questions in the first part require factual information from the participants such as age, the duration of foreign language learning study, the second part includes five-point Likert scale ranging from (1) never true, (2) usually not true, (3) somewhat true, (4) usually true and (5) always true. Additionally, as stated by Petric and Czarl (2003) "the main part, dealing with strategies, is divided into three subsections: planning strategies ( 8 items), while-writing strategies (14 items), and revising strategies (16 items). In brief, the questionnaire included 38 subdivided items in total." (p. 190). As the researchers point out such a classification was made in order to examine the participants' writing strategy choices in depth.

In addition to the questionnaire, to obtain more specific data concerning students' perceptions on use and effectiveness of writing strategies, and to supplement information which allows both the freedom of talking by the interviewee to some extent and control by the interviewer in a similar way interview technique was used in the present study (Bryman, 2004). The first question was on the examination of the challenges faced by students in the writing process before involving in writing strategy training. The second question was directed to reveal the perceptions and attitudes of the students towards the use of strategies respectively in before writing, when writing and after writing stages of the writing process respectively.

\subsection{Data Collection Procedure}

The current study used a sequential mixed-methods design in data collection procedure. As Creswell and Clark (2011) illustrate, a sequential mixed method data collection procedure is based on collecting two types of data in an asynchronous way. In the present study, first, quantitative data and then qualitative data were collected. As for the qualitative data, a 5-point Likert writing strategy questionnaire developed by Petric and Czarl (2003) was used consisted 
of 38 items. The pretest questionnaire was conducted in the first week while the post-test at the end. Data collection process including the writing strategy instruction lasted 14 weeks in 2017-2018 academic year. The students in experimental group received writing strategy training in addition to writing instruction during 14 weeks.

At the end of the training, a semi-structured interview that required the reflection of students' perceptions related to writing strategy training and the difficulties they faced before writing strategy training was used as a qualitative data collection tool. The answers were recorded and transcribed later. Before conducting the interview, the researcher explained the purpose and format of the interview to the participants. Then, the participants were ensured that their names would not be revealed to protect their identities and their permission was taken as their quotes would be used. In addition to preparing the interview setting to avoid certain problems regarding the comfort of the participants, several measures were also taken for validity and reliability of the interview. The first step for providing the quality of the interview questions, was the use of a pilot scheme. Based on piloting, the incompetent aspects in questions were improved and edited and a new one was developed. To have more credible data, the researcher had also a guidance from an expert who is experienced in research.

\subsection{Data Analysis}

The data analysis was provided through Statistical Package for the Social Sciences (SPSS) 22 program. Throughout the analysis procedure, the data were analyzed through different statistical tests. To determine the reliability of the instrument, The Cronbach Alpha coefficiency test result was carried out. The results are demonstrated in Table 2.

Table 2. Reliability Analysis of WSQ

\begin{tabular}{llll}
\hline & $\mathrm{N}$ (Cases) & $\mathrm{N}$ (Items) & $\boldsymbol{\alpha}$ \\
\hline Before & 78 & 8 & .571 \\
While & 78 & 14 & .636 \\
After & 78 & 16 & .852 \\
Total & 78 & 38 & .879 \\
\hline
\end{tabular}

As it is shown in Table 2, the reliability co-efficiency of the questionnaire in total was .879 . As the reliability coefficient of an instrument should be above 
.70 to accept the instrument as reliable, the questionnaire applied in the current study has a high internal-consistency reliability.

As a second step, for non-normally distributed before-writing stage strategy use values, Mann-Whitney U-test was implemented. The results were shown in Table 3.

Table 3. Mann-Whitney U test Related to Before Writing Strategy Use by Experimental and Control Groups

\begin{tabular}{ccccccc}
\hline Before ws & $\mathrm{n}$ & Groups & $\overline{\mathrm{X}}$ & $\mathrm{SD}$ & $\mathrm{z}$ & $\mathrm{p}$ \\
\hline & 37 & Experimental & 29.08 & 4.96 & -1.65 & .098 \\
& 42 & Control & 27.11 & 5.34 & & \\
\hline
\end{tabular}

The table presents the results of Mann-Whitney U- test which is used when the test does not provide the information of any properties concerning the distribution of the dependent variable in the analysis (Refugio, 2018). ShapiroWilk test was performed to find normality of the data distribution. The results have shown that the answers for the items related to while, revising and total strategy use significance values were $.160, .182$ and .211 respectively. As Shapiro-Wilk-values are greater than 0.05 , it can be indicated that the data are normally distributed (Ghasemi \& Zahedias1, 2012). For this reason, for the analysis of data parametric tests were used. Depending on p-values' being greater than 0.05 , it can be concluded that each variable was homogeneous. Thus, it was proper to use independent-samples t-tests to examine the difference between and among the variables.

In order to analyze the qualitative data, content analysis was employed for the answers of open-ended questions. That is, the present study, avoided using pre-planned categories, instead read the data word by word and derived meaningful subjects. The researcher read the quotations of the interviewees repeatedly with the intent of comprehending and tagging key phrases and segments corresponding to research questions. That is, based on this inductive reasoning process, codes were developed and sorted into relevant categories. Regarding the coding process, Creswell (2012) states that "make sense out of text data, divide it into text segments, label them with codes, examine codes for overlap and redundancy, and collapse these codes into broad themes, and this process involves identifying text segments, placing a bracket around them, and assigning a code word" (p. 244). In light of these statements, the researcher analyzed the content and found significant data to categorize. 


\section{Results}

In this section, quantitative and qualitative results of the data analysis are presented systematically through tables.

\subsection{Quantitative results}

In this section, the result of data analysis of writing strategy questionnaire is presented in detail through the help of tables.

First, a pretest for writing strategy use at three stages for control and experimental groups was performed. The main test for the assessment of the normality was Shapiro-Wilk test. The test compared the scores in the samples whether they were normally distributed. The Mann-Whitney U-test results demonstrate that values of before writing strategies were 0.50 , while was 0.18 and after writing strategies were, .135; that is, they were distributed normally ( $p>0$, 05). However, the total use of writing strategies for two groups in pre-test was .005 , that is, the data distributed non-normally $(\mathrm{p}<0,05)$. Therefore, for normally distributed data independent t-test was implemented while for the non-normal, Mann-Whitney U-test was applied. Table 4 shows the results for independent ttest.

Table 4. Independent t-test Results Related to Writing Strategy Use at Three Stages by Experimental and Control Groups.

\begin{tabular}{lllcccc}
\hline & $\mathrm{n}$ & Groups & $\overline{\mathrm{X}}$ & $\mathrm{SD}$ & $\mathrm{t}$ & $\mathrm{p}$ \\
\hline \multirow{2}{*}{ Before } & 43 & Experimental & 20.32 & 5.69 & 1.34 & 0.183 \\
& 37 & Control & 18.51 & 6.35 & 1.33 & 0.186 \\
\cline { 2 - 7 } While & 43 & Experimental & 43.39 & 8.56 & 0.142 & 0.808 \\
& 37 & Control & 43.13 & 7.75 & 0.143 & 0.887 \\
\cline { 2 - 7 } Revising & 43 & Experimental & 41.97 & 8.76 & -0.115 & 0.909 \\
& 37 & Control & 42.18 & 7.61 & -0.116 & 0.908 \\
\hline
\end{tabular}

The results indicate that there is no statistically meaningful difference for the use of writing strategies in three stages between experimental and control groups in the pre-test. As displayed, $p$ values were 0.888 and 0.887 for strategies employed in while writing stage, 0.909 and .908 for strategies employed in revising stage and lastly 0.183 and 0.186 for strategies employed in before writing stage for experimental and control groups respectively $(p>0,05)$. That is, there is no statistically meaningful difference between experimental and control group 
students in terms of frequency of strategy use in three stages and total use of writing strategies at pre-test. For non-normally distributed total strategy use Mann-Whitney U- test was used. The results were shown in Table 5.

Table 5. Mann-Whitney U-test Related to Total Strategy Use by Experimental and Control Groups

\begin{tabular}{llcccc}
\hline $\mathrm{n}$ & Groups & $\overline{\mathrm{X}}$ & $\mathrm{SD}$ & $\mathrm{z}$ & $\mathrm{p}$ \\
\hline 43 & Experimental & 105.69 & 19.735 & -.575 & .566 \\
37 & Control & 103.83 & 18.783 & & \\
80 & Total & 104.83 & 19.202 & & \\
\hline
\end{tabular}

According to the results shown in Table 22, the ratings of EFL students between experimental and control groups did not display a significant difference in total strategy use in pre-test (total=.566; $<<0,05$ ). This means that before strategy training, participants in experimental and control groups showed no significant difference in total strategy use.

The present study also aims to find whether a 14-week writing strategy training would increase the EFL learners' frequency of writing strategy use . First, Shapiro-Wilk test was performed to find normality of the data distribution. The results have shown that the answers for the items related to while, revising and total strategy use were distributed normally as their significance value were .160 , .182 and .211 respectively. Therefore, independent t-test was applied. Table 6 shows the results.

Table 6. Independent t-test Results for Use of Writing Strategies by the Experimental and Control Groups in Post-test

\begin{tabular}{ccccccc}
\hline & $\mathrm{n}$ & Groups & $\overline{\mathrm{X}}$ & $\mathrm{SD}$ & $\mathrm{t}$ & $\mathrm{p}$ \\
\hline \multirow{2}{*}{ While } & 37 & Experimental & 49.72 & 6.39 & 1.26 & .211 \\
& 42 & Control & 47.73 & 7.50 & 1.27 & .207 \\
\multirow{3}{*}{ Revising } & 37 & Experimental & 52.78 & 10.78 & 10.78 & .002 \\
& 42 & Control & 44.66 & 11.23 & 11.23 & .002 \\
\hline
\end{tabular}

Based on the results of the independent t-test, it can be indicated that there is a statistically meaningful difference between experimental and control groups in terms of the values for strategy use in revising stage $(p=002 ; p<0,05)$. That is, participants in the experimental group used revising strategies more frequently compared to participants in the control group. However, no meaningful difference 
was found between two groups in terms of scores for while writing strategy use $(\mathrm{p}=.211 ; \mathrm{p}>0,05)$.

For non-normally distributed before writing stage strategy use, MannWhitney U-test was implemented. The results were shown in Table 7.

Table 7. Mann-Whitney U-test Related to Before Writing Strategy Use by Experimental and Control Groups

\begin{tabular}{lllllll}
\hline & $\mathrm{n}$ & Groups & $\overline{\mathrm{X}}$ & $\mathrm{SD}$ & $\mathrm{z}$ & $\mathrm{p}$ \\
\hline \multirow{2}{*}{ Before } & 37 & Experimental & 29.084 .96 & -1.65 & .098 \\
& 42 & Control & 27.115 .34 & & \\
\hline
\end{tabular}

According to the results shown in Table 24, the ratings of EFL students between experimental and control groups displayed a significant difference in employing before writing strategy use $(\mathrm{p}=.098 ; \mathrm{p}<0,05)$. This means that after strategy training, participants in experimental group showed a significant difference in before writing strategy use compared to the control group.

The frequency of strategy use at three stages of writing for experimental and control groups is also taken into consideration in this study. Descriptive statistics were given in Table 8.

Table 8. Descriptive Statistics for Frequency of Strategy Use at Three Stages by Experimental and Control Groups

\begin{tabular}{lllll}
\hline & $\mathrm{N}$ & Group & $\overline{\mathrm{X}}$ & $\mathrm{SD}$ \\
\hline \multirow{2}{*}{ Before } & 37 & Experimental & 29.08 & 4.96 \\
& 42 & Control & 27.11 & 5.34 \\
\cline { 2 - 5 } While & 37 & Experimental & 49.72 & 6.39 \\
& 42 & Control & 47.73 & 7.50 \\
\multirow{2}{*}{ After } & 37 & Experimental & 52.78 & 10.78 \\
& 42 & Control & 44.66 & 11.23 \\
\multirow{2}{*}{ Total } & 37 & Experimental & 134.97 & 19.59 \\
& 42 & Control & 122.80 & 21.47 \\
\hline
\end{tabular}

As Table 8 demonstrates, the students in the experimental group used strategies more frequently at revising stage, while writing stage and before writing stage respectively. Given the results for descriptive analysis, it can be stated that the students in the control group employed strategies most frequently in while writing strategies stage, then, revising strategies and before writing respectively. 
The other result found by descriptive analysis is that the overall frequency of strategy use of students in the experimental group is higher than those of students in the control group. The mean rating score of total strategy use by participants in the experimental group was 134.9 whereas it was 122.8 for the control group.

\subsection{Qualitative Results}

The results of the semi-structured interviews conducted with 24 students out of the experimental group, are presented in this part. It was directed with students from experimental group due to their experience of receiving instruction in writing strategies for fourteen weeks. The interview questions were in English; however, it was the participants' choice to answer whether in Turkish or English. The participants were enabled to participate freely. The guiding questions of the interview were based on the research questions of the study were as follows;

1. What are the challenges do students in English Language and Literature department encounter in the process of writing?

2. What are the perceptions and attitudes of the students in the experimental group towards the use of strategies in before writing, when writing and after writing stages of the writing process?

\subsubsection{Theme 1: The challenges faced by students in the writing process before involving in writing strategy training.}

The difficulties and challenges faced in the process of writing were among the important considerations of the writing strategy training. The analysis of the oral data related to this issue categorized into codes. The following table presents the codes about the challenges that are experienced in the process of writing before writing strategy training.

Table 9. The Theme for the Challenges Faced in the Writing Process

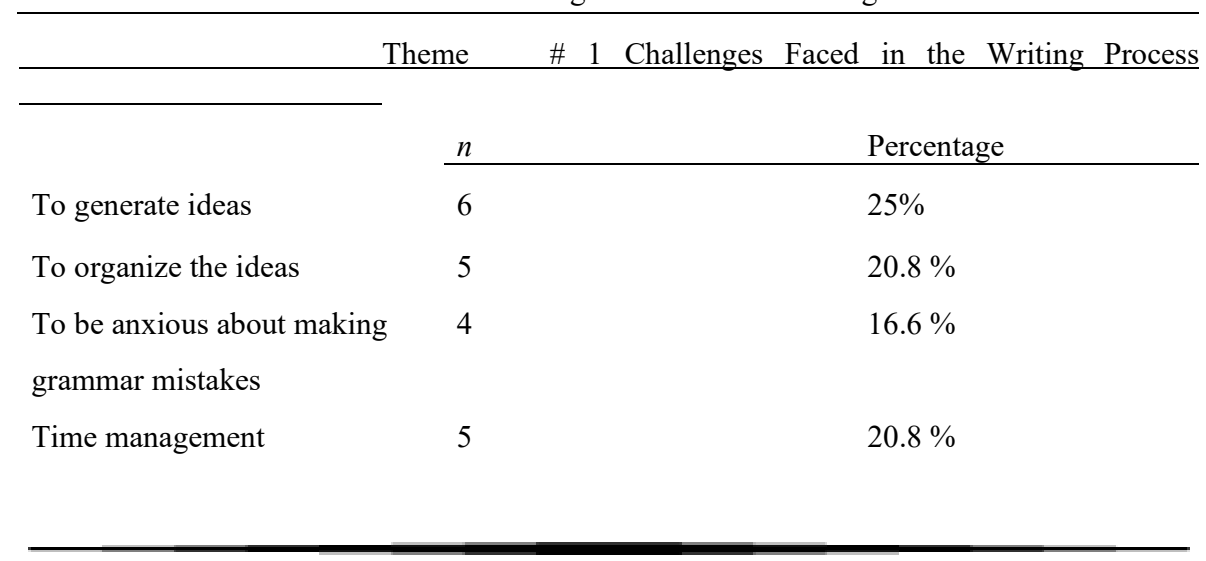


To find proper vocabulary

$12.5 \%$

To use punctuation rules 1

$4.1 \%$ properly

The data collected via interview revealed that students face various problems in writing process. One of the most prominent difficulty is to find ideas concerning the writing prompt before writing and they complained of experiencing this problem during the writing process. The second challenge faced by students, as Table 9 shows, was organizing the ideas. Another point that the table shows as a problem was anxiety about making grammar mistakes in essays. The problem of time management also takes a crucial place in participants' responses. Another issue highlighted by these participants is their negative perceptions regarding their limited vocabulary knowledge; therefore, they reported that they spent too much time and effort on choosing proper words. Organizing ideas properly was also considered as a problem by the participants. The students drew also attention to managing the time while writing. Some of the learners' statements as follows illustrate all these points:

I believe I have a good level of grammar knowledge; however, I couldn't take good grades in writing course. I think this problem stemmed from my confusion in deciding what to write. I want to say that even if I come across with a simple topic, I had difficulty about finding ideas. In fact, I had many things in my mind; however, I couldn't decide which one would go in my essay. When I found something to write, in the middle of the essay, again I experienced same problem, therefore I wrote randomly because I didn't want to lose time.

It took my hours to write as I couldn't organize what I had in my mind. I couldn't find ideas, when I found, I had constantly changed my mind during writing. I changed my mind, my structure and my words as they sounded odd when I read them. I couldn't achieve unity and logical order; therefore, I had to begin the essay again and again.

I think most important thing in writing is grammar. If we don't use true grammar, we couldn't express ourselves. I do many grammar wrongs and especially I don't know which transition signals I will use. I am bad at conjunctions. Also I only use simple sentences and common tenses in my essay not complicated sentences but my friends have.

I think I am good at writing in general, but I am not able to choose the best words for my essays weird words and they don't give the meaning I want to 
convey. Also, when I compare my essays with more proficient writers I see that I use simple and easy words. Therefore, I want to change them.

Even if I find what to say and write about, I cannot finish the essay in the given duration. When I focus on grammar, content and organization, I have no time to complete my essay.

3.1.2. Theme 2: Writing Strategies Employed in Prewriting, While Writing and Post Writing Stage

The second theme examines the strategies used at three stages of the writing process. The analysis of written data related to the perception of the students who received strategy training has revealed that use of writing strategies at different stages of writing have positive contributes to the perceptions of participants about their improvement in the writing skills. The following table displays the codes related to the strategies employed in before-writing stage.

Table 10. Writing Strategies Employed in Prewriting Stage

\begin{tabular}{|c|c|c|}
\hline \multicolumn{3}{|c|}{$\begin{array}{l}\text { Theme \# } 2 \text { Writing Strategies Employed in Prewriting } \\
\text { Stage }\end{array}$} \\
\hline & $\mathrm{n}$ & Percentage \\
\hline Outlining & 8 & $33.3 \%$ \\
\hline Clustering & 5 & $16.6 \%$ \\
\hline Freewriting & 3 & $12.5 \%$ \\
\hline Looking at a model & 3 & $16.6 \%$ \\
\hline Brainstorming & 6 & $20.8 \%$ \\
\hline Forming a timetable & 1 & $4.16 \%$ \\
\hline
\end{tabular}

The data on the strategies used for prewriting stage revealed that most of the students after strategy training employed strategies at before writing step to overcome the difficulties they face in the writing process. As shown in Table 10, the use of outline was the most frequently reported strategy which was followed by brainstorming, clustering, looking a model by a proficient write, free writing and forming a timetable subsequently.

Table 11. Writing Strategies Employed in While-writing Stage

Theme \# Writing Strategies Employed in While-writing Stage

$\mathrm{n}$ 


\begin{tabular}{|c|c|c|}
\hline Required focus on structure & 10 & $41.6 \%$ \\
\hline Writing ideas down quickly & 11 & $45.8 \%$ \\
\hline Taking regular breaks & 18 & $75 \%$ \\
\hline Starting with body paragraphs & 4 & $16.6 \%$ \\
\hline Sharing and responding with writing group & 7 & $29.1 \%$ \\
\hline Writing down words in native language when not remembered & 5 & $20.8 \%$ \\
\hline \multicolumn{3}{|c|}{$\begin{array}{l}\text { The data on the participants' perceptions concerning the use of writing } \\
\text { strategies at while writing stage revealed that there are positive contributions of } \\
\text { strategy employment while writing. Table } 12 \text { summarizes the themes and codes. } \\
\text { Table 12. Writing Strategies Employed in Post-writing Stage }\end{array}$} \\
\hline \multirow[t]{2}{*}{ Theme } & \multicolumn{2}{|c|}{ Post-writing Stage } \\
\hline & $\mathrm{n}$ & Percentage \\
\hline Revising respectively & 10 & $41.6 \%$ \\
\hline Revising with an outline & 5 & $20.8 \%$ \\
\hline Having a cool-off period & 3 & $12.5 \%$ \\
\hline Reading the text aloud & 4 & $16.8 \%$ \\
\hline Comparing and responding essays within groups (s) & 10 & $41.6 \%$ \\
\hline
\end{tabular}

The data on the scope of strategies employed at post-writing stage revealed that most of the participants were in favor of the use of strategies in this step. As illustrated in Table 12, most of the participants mainly favored revising their essays respectively. The participants who supported revising the essays in a systematic order explained that before strategy training they could not allocate time to revise their essays. They claimed strategy training was a contributory factor to the save of time. Additionally, use of revising strategy for their essays in a clear order increased the quality of writing. To illustrate, they revised their essays in a systematic order such as revising the content and organization, revising the grammar by creating a checklist for it, and then revising for punctuation rules and lastly editing the essay. Several comprehensive statements by learners regarding their perceptions towards the strategy use at different stages are as follows:

All of the prewriting strategies are so helpful; however, the most appealing one for me is outlining. It helps me write more effectively as I have a plan in my 
mind. Before learning strategies, I couldn't decide how to start, how to go, similarly how to end. From now on, I am able to follow a way which I designed at the beginning of the process thanks to outline. I use my eraser less and save time and save my energy. After I design an outline, I can say that $50 \%$ of my essay is completed.

Before knowing that taking a break is useful, I tried not to stop and have a break. I felt guilty when I stopped because when I looked around all of my classmates were writing without stopping in exams. Now, when I am bored or feel stressed I think it is time to have a break. Then, I refresh my ideas and turn back in a more positive mood.

I reread my essay in several stages. I go through my first draft and care for the organization, supporting ideas and arrangement of ideas. Then, I revise the examples and details. The last step is to revise my essay in terms of grammar mistakes, vocabulary choice, and punctuation mistakes. When I revise for grammar, I have a plan about how to check it. For example, firstly I check for tenses, conjunctions and then subject agreement and so forth. When I do this, I have a clear path and this provides success for my essay.

Sometimes my sentences are not correct in terms of grammar. I cannot see my mistakes when I revise. However, when I read my essay aloud, I eliminate the odd sentences, ideas and structures. When I have time and place, I try my best to read the text aloud. Sometimes hearing my own voice helps me to put myself in the reader's or teacher's position.

\section{Discussion}

This section presents the discussion based on the results of the qualitative and quantitative data. The discussion is provided in parallel to relevant research findings.

The participants emphasized that they put great importance on the linguistic structure while the content of the essay remained as a neglected component. At this point, it can be assumed that the students' giving great importance and focusing intensively on the grammatical structures made them feel anxious while writing since EFL learners view structural issues, particularly grammar aspect, as a problem. This result is important as it would suggest that EFL writing instructors should take into consideration the hesitations of learners regarding using linguistic elements successfully as this anxiety might be a barrier for learners which the relevant literature also supports. In his examination of the 
difficulties students face in writing process, Klimova (2014) found that most of the students complained about the use of a formal language and they hesitated about making grammar mistakes too much. At this point, it is possible to suggest that this challenge in writing process could be overcome if writing instructors enable their students use appropriate writing strategies as noticing strategies at each stage has the potential of raising awareness about different dimensions of writing process instead of regarding grammar as the vital and mere factor of text.

In the current study, 5 out of 24 participants reported their sense of difficulty in time management skills in completing the essay task on time. Additionally, they believed that their deficiency in time management leads to anxiety and accordingly demotivates them. After involvement in the strategyinstruction, they believed that they can develop their writing skills if they plan by implementing one of the before writing skills. Given the perceptions of the participants in the present study concerning the relationship between time management, anxiety and academic motivation, the study of Ghiaswand, Naderi, Tafreshi, Ahmendi and Hosseini (2017) display similar results as their study showed a positive relationship between time management skills, anxiety and academic motivation. Based on the results of oral data, it can be asserted that implementing writing strategies, particularly, in before writing stage, can lead to positive attitudes towards writing skills as it develops time management skills, saves time which, in turn, motivates students to write in the target language.

One of the greatest concerns of these student participants was the difficulty in generating ideas and organizing them in a meaningful pattern. This finding is also supported by that of Fareed, Ashraf and Bilal (2016) whose studies investigated the problems ESL learners face and revealed that students mainly suffer from lack of ideas and weak organization in writing process. Regarding the motives behind these challenges, there might be various influential factors; however, the corporation of the writing strategies into the writing instruction may be suggested as one of the remedial measures as the present study shows. The consideration of the expressions provides the implication that the participation in writing strategies raised students' awareness concerning the role of the planning stage in writing task, thereby enabling students to allocate time to carry out strategies for the before writing stage.

One of the ultimate goals of the present study was to find the perceptions of EFL pre-intermediate students towards the use of writing strategies at three stages of the writing process. 
Oral data demonstrated that use of outlining decreased the time allocated on writing. In addition, based on the results, it can be indicated that the outline may be a guide for students to generate ideas and to organize the content of the essay. Therefore, it seems possible to suggest that outlining is significant in improving the quality of text in terms of presenting a wide range of ideas related to the topic. In a similar vein, to understand the effect of prewriting strategies on the writing process, Smet, Gruwell, Leijtenn and Kirschner (2014) examined the impact of electronic outlining strategy on the argumentative writing performance in prewriting stage, and point out the profit of outlinining to organize the texts in an effective manner. In addition, outlining affected the total used time and writing fluency. Based on the participants' beliefs in the current study and the consistent literature, it can also be inferred that use of prewriting strategies particularly outlining may increase writing achievement as it creates a positive attitude and perception towards writing in foreign language and lessens the anxiety about inefficient time management. It can be suggested that the construction of different prewriting strategies help students to determine the pattern to go through in the writing process.

As for the clustering strategy, many participants stated their favors as it enabled students to eliminate the unnecessary ideas, to have association and generate ideas proper for the content through visualization. This result implies that explicit instruction of clustering strategy may be beneficial for visual learners as they can follow the visual diagram while writing and composing the content. Addressing the role of clustering strategies, these results are in the line of Adriati's (2013) who investigates the effect of clustering strategy in teaching writing a narrative text with an experimental designed research. In his examination of whether use of clustering strategy was helpful for the development of writing skills or not, the researcher found that clustering strategy instruction had a significant role in improving students' performance in writing a narrative text. The conclusion drawn from this finding is that applying clustering strategy increases students' motivation and achievement in writing; therefore, language teachers should design and organize their lesson plan which supports the employment of prewriting strategies one of which is clustering in order to enable their students to generate ideas and link them in an arrangement.

The participants reported using various while writing strategies to struggle with the problems in the writing process. Data from the interview displayed that after strategy instruction, students did not allocate much time for mechanical and grammatical issues. That is to say, rather than concentrating merely on linguistic 
and lexical elements they also focused on content. In turn, this strategy helped them to feel less anxious in the writing process. The results showed that giving full attention to grammar and vocabulary restricted student participants to follow certain requirements such as composing ideas and arranging the content. Thus, they no more look up continuously for the equivalence of the lexical items and viewing writing from just a structural perspective which in turn enabled them to have better essays through multiple drafts. Conducted with a similar purpose to that of the present one, the study of Maaroof and Murat (2015) focused on while writing stage strategies suggesting the employment of strategies at while writing stage as a means of enriching the development of writing skill. The implication driven from this result for language teachers is that encouraging students to use various strategies particularly at while writing stage to improve students' writing skills.

The present study also reveals that a favorable percentage of students reported the use of their native language when they need. Based on the oral statements, it can be stated that the possible benefit of use of L1 when the learners did not remember the target language ones is that it encourages students to maintain the writing process and prevents the loss of time which is one of the most encountered problems reported by the participants. However, this result is not consistent with that of Baker and Boonkit (2004) in which low proficient students used bilingual dictionaries in writing task while the high achievers only used monolingual dictionaries. Therefore, it is a need to investigate the effect of strategy of using native words when there is a difficulty in remembering the target equivalent on writing performance.

One point the participants mostly voiced during the interviews was "revising respectively" strategy. The result of the oral data in the current study indicated that students had positive perceptions on the use of revising strategies through checklists and an outline. Conclusion of the present study provides that revising an essay by dividing it into sections such as revising for use of tenses, vocabulary and conjunctions can be more beneficial than revising the texts as a whole because this strategy enables learners to focus on different components of an essay and turns writing task into a more manageable task. In addition, the participants' awareness regarding the dimensions of a writing task related to issues such as point of view, coherence, unity, word choice and organization increased through revising respectively strategy. To make corrections and to divide the writing task into sub goals through checklist or rubrics might lead to an easier and detailed revising. This result supports that of Doroudi and Kasmani 
(2016). In their examination of the effect of planning prewriting and post writing strategies on Iranian Intermediate EFL learners' paragraph writing ability, they revealed that the learners who received post writing strategies, particularly those who used revising respectively strategy, performed better in terms of essay writing when they took part in the writing process. In this sense, it can be commented that post-writing strategy use has a potential for improving the writing quality in EFL context. At this point, it can be noted that most of the students reported use of revising respectively strategy as to plan an order to revise their essays e.g revising the structure, the punctuation, the organization, spelling and word choice provides a systematic order which enables a more precise and practical revision. It can be concluded from the results that the writing instructors are confronted with the need of post-writing stage strategies instruction specifically to raise awareness concerning revising a text in a strategic way.

In addition to benefit of revising the essay systematically, the findings of the study revealed that having a cool-off period strategy is worth mentioning as it increases students' awareness of the essay and contributes to their self-confidence as well. Based on the participants' beliefs, it can be assumed that if time is available to additional reading, students tend to see the unforeseen mistakes, in turn, they feel less stressful and more confident. Thus, it is possible to note that teachers' instructing learners about this strategy and adjusting the length of the deadline may lead to improvement in text and enhances the self-confidence of learners.

Based on the remarks of participants regarding revising strategy, it can be inferred that they also benefitted from the "reading aloud" strategy. The remarks of students show that this strategy leads to self-edition which assures them to overcome the obstacles in the writing process such as anxiety, lack of selfconfidence, and inability to see the text from the point of audience. In this regard, it can be suggested that reading aloud strategy removes the difficulty in detecting the problems in students' own text. Similarly, the students' comments reveal that misspelled and overlooked errors are seen in by reading aloud technique. Based on the consideration of the results, it can be suggested that this study reveals that instruction in writing strategies at revising stage of writing process is central in foreign language education as stated by the participants of the current study; however which dimension of writing task develop after post-writing strategy needs further investigation. 
On the basis of questionnaire results, the present study showed that explicit training in writing strategies for each stage such as prewriting, during writing and post writing increased the frequency of use of writing strategies by students. The remarks of students in experimental group also supplied an additional evidence for the quantitative results, as students in the experimental group stated that explicit strategy training enabled them to choose types of strategies that fit them which in turn motivated them to use these strategies more frequently. The result of this study is significant as it demonstrates that enabling learners to choose their own style of strategy might contribute to independency and motivation of learners in learning process as confirmed by participants. This positive effect of explicit strategy training on the improvement of writing skills is also revealed by that of Mastan and Maarof's (2014) who favored the explicit training to provide learners to choose the right type of strategies to help them. In their examination on the effect of writing strategy training in ESL context on the improvement of performance in writing, they recommended explicit training of various strategies for the development of writing skills in second language classrooms. Therefore, it can be indicated that their suggestion is consistent with the results of the present study as both of them refer to explicit strategy training to help second language learners become more successful and independent writers. This conclusion supports that of Wischgoll (2017). The researcher regards writing strategy training as favorable as it affects academic writing skills positively and also it affects the quality of the texts in a positive way. Thus, it can be indicated that strategy training in writing courses may contribute to the confidence, independency, and motivation of language learners.

\section{Conclusion}

The findings of the qualitative and quantitative data demonsrated that writing strategy instruction has positive effects on students' perceptions towards writing process. The examination of the qualitative data obtained from language learners revealed that writing strategy training has a positive effect on the improvement of writing performances of students majoring in English. The writing difficulties encountered by the experimental group of students were generating ideas, organizing the content, anxiety about making mistakes in grammar, having difficulty in using spelling and punctuation rules, using proper words, and managing the time. It was revealed from the results, most of the participants experienced less difficulty in the points aforementioned due to the use of different writing strategies at each stage of writing consisting of prewriting, while writing and after writing processes. That is to say, they benefited from 
strategy training to develop their academic writing skills. Relating these results, it can be proposed that employment of strategies in the writing process can promote specific skills such as time management, motivation to write, creating ideas, and a decrease in anxiety. Thus, writing instructors should be aware of the particular problems that the students face and find a solution in parallel to the proper writing strategy. To illustrate, the students who specifically had problems in generating ideas noted that they overcome this difficulty by the use of prewriting techniques one of which is mainly brainstorming. At this point, the instructors are responsible in addressing the exact problem and accordingly enabling the learners to use the necessary strategy.

Therefore, this study shed light upon the role of teacher since she/he should allocate and adopt time for introducing these strategies to students to create awareness about the benefit of strategy use in solving the problems in the writing process. Writing instructors and practitioners should integrate the explicit writing strategy training into the process-oriented writing instruction. The main suggestion for writing instructors should be a deep research in the relevant literature for a deep understanding of learning strategies, and particularly for the studies concerning the writing skill. In this regard, it can be suggested that writing course instructors need to improve their professional development through participating in seminars, conferences and workshops related to strategy training. For this purpose, language teachers should arrange and devote more time to teach and integrate strategies in the already existing curriculum, make students receptive for their new roles in language learning process by instructing them on the importance and implementation of strategy use.

Another suggestion is to integrate strategy training into language programs of pre-service teachers to raise their awareness and knowledge about strategies. That is, language teacher programs should provide opportunities for teacher candidates to recognize the significance of the strategies. Therefore, additional instruction on strategies is needed in writing courses in language teacher programs for professional development. 


\section{References}

ADRIATI, M. (2013), "The use of clustering technique in teaching writing narrative text", Journal of English and Education, 1 (2), 39-46. Retrieved from:

https://pdfs.semanticscholar.org/531a/57ccc427f1c7b6f5e852bc1cf5635 aa38b37.pdf

ALHAYSONY, M. (2017), "Language learning strategies use by Saudi EFL students: The effect of duration of English language study and gender", Theory and Practice in Language $\quad$ Studies, $\quad 7(1), \quad 18-$ 28.doi:10.17507/tpls.0701.03

ALIAS , A. A., MANAN, N., YUSOF, J., \& PANDIAN, A., (2012), "The use of facebook as language learning strategy (1ls) training tool on college students' 1ls use and academic writing performance", Procedia Social and Behavioral Sciences, 67(3), 36-44 doi:10.1016/j.sbspro.2012.11.305

ALLODWAN, T. A., \& IBNIAN, S. S. (2014), "The effect of using the process approach to writing on developing university students' essay writing skills in EFL", Review of Arts and Humanities, 3(2),139-155. Retrieved from :http://rahnet.com/journals/rah/Vol_3_No_2_June_2014/11.pdf

ALKUBAIDI, M., (2014), "The relationship between Saudi english major university students' writing performance and their learning style and strategy use", English Language Teaching, 7(4), 83-95. doi: 10.5539/elt.v7n4p83

ARNDT, V. (1987), "Six writers in search of texts: A protocol-based study of L1 and L2 writing", ELT Journal, 41(8), 257-267. Retrieved from http://citeseerx.ist.psu.edu/viewdoc/download?doi=10.1.1.464.4662\&re $\mathrm{p}=\mathrm{rep} 1 \&$ type $=$

BAI, B. (2016), Writing strategies and strategy-based instruction in Singapore primary schools, Cambridge Scholars Publishing.

BAKER, W., \& BOONKIT, K. (2004), "Learning strategies in reading and writing: EAP contexts", Relc, 35(3), 299-328. doi:10.1177/0033688205052143

BROWN, D., (2006), Principles of language learning and teaching (Fifth Edition), Pearson Longman Publishing. 
BRYMAN, A. (2004), Social research methods (2nd edition), Oxford: Oxford University Press.

CHU, W., LIN, D., CHEN, T.,TSAI, P.,\& WANG, C. (2015), “The relationships between ambiguity tolerance, learning strategies, and learning Chinese as a second language", Procedia - Social and Behavioral Sciences , English Teaching Forum, 49(2), 26- 33. doi: 10.1016/j.system.2014.10.015

COHEN, A.D., \& DÖRNYEI, Z. (2002), "Focus on the language learner", In: Schmitt, N. (Eds.), An introduction to applied linguistics. London: Arnold Hodder.

CORNETT, C. E. (1983), What you should know about teaching and learning styles, Bloomington: Phi Delta Kappa Educational Foundation Press.

CRESWELL, J. W. (2012), Educational research: Planning, conducting, and evaluating quantitative and qualitative research (4th ed.), Boston, MA: Pearson.

DÖRNYEI, Z. (2005), The Psychology of language learner: Individual differences in second languageacquisition. London: Mahwah, NJ. Lawrence Erlbaum.

DUJISIK, D. (2008), The effect of prewriting strategy training guided by computer-based procedural facilitation on ESL students' strategy use, writing quantity and writing quality (Unpublished doctoral dissertation), Retrieved from http://www.scholarcommons.usf.edu/etd/221.

ELLIS, R. (2004), Individual differences in second language learning, Oxford: Blackwell

FAREED, M., ASHRAF, A., \& BILAL, M. (2016), “ESL learners' writing skills: Problems, factor and suggestions", Journal of Education and Social Sciences, 4 (2016), 81-92. https://doi.org/10.20547/jess0421604201

GARDNER, R. C. (1985), Social psychology and second language learning: The role of attitudes and motivation, London: Edward Arnold Publishers.

GHASEMI, A. \& ZAHEDIASL, S. (2012), "Normality tests for statistical analysis: A guide for non- statisticians", International Journal of Endocrinology Metabolism 10(2),486-489. Doi: 10.5812/ijem.3505

GHIASVAND, M. , NADERI, M. ,TAFRESHI, M. , AHMEDI, F. , \& HUSAINI, M. (2017), "Relationship between time management skills 
and anxiety and academic motivation of students in Tehran", Journal of Electronic Physician, 9(1), 3678-3684. doi: 10.19082/3678.

GRIFFITHS, C. (2008), Lessons from good language learners, Cambridge: Cambridge UP

KLIMOVA, B. (2014), "Approaches to the teaching of writing skills", Procedia - Social and Behavioral Sciences, 112(2014), 147-151. doi: 10.1016/j.sbspro.2014.01.1149

LEKI, I. (1995), "Coping strategies of ESL students in writing tasks across the curriculum", Teachers of English to Speakers of Other Languages, Inc. (TESOL), 29(2), 235-260. doi:10.2307/3587624

LONG, M. (1990), "Maturational constraints on language development", Studies in Second Language Acquisition 12, 251-285. doi:10.1017/S02722631000009165

MAAROF, N., \& MURAT, M. (2015), "Writing strategies used by ESL upper secondary school students.Canadian center of science and education", International Education Studies, 6(4),47-58. doi: 10.5539/ies.v6n4p47

MANOUCHEHRY, A., FARANGI, M.R., FATEMI, M.A. \& QAVIKEFT, F. (2014), T'he effect of two brainstorming strategies on the improvement of Iranian intermediate EFL learners' writing skill”, International Journal of Language Learning and Applied Linguistics World (IJLLALW), 6 (4), 176-187.

MASTAN, M.E. \& MAAROF, N. (2014), “ESL learners' self-efficacy beliefs and strategy use in expository writing", Procedia - Social and Behavioral Sciences 116, 2360 - 2363. doi: 10.1016/j.sbspro.2014.01.573

MOHAMMADI, M., BIRJANDI, P., \& MAFTOON, P. (2015), "Learning strategy training and the shifting learners' beliefs about language learning: a reading comprehension context", Sage Open Publication, 1(11), 11-25. doi:10.1177/2158244015579726

NASIHAH, M., \& CAHYONO, B.Y. (2017), "Language learning strategies, motivation, and writing achievement of Indonesian EFL students", Arab World English Journal (AWEJ), 8(1), $250 \quad 263$.

doi:10.24.093/awej.vol8no1.18 
O’MAlley, J., CHAMOT, A., MANZANARES, G., ROCCO, P. R., \& KUPPER, L. (1985), "Learning strategy applications with students of English as a second language", TESOL Quarterly, 19(3), 557-584. doi: $10.2307 / 3586278$

O'MALLEY, J. M., \& A. U. CHAMOT (1990), Learning strategies in second language acquisition, Cambridge: Cambridge University Press.

ONOZAWA, C. (2010), “A study of the process writing approach”, Journal of Kyoai Gakuen College, 10, 153-163.

Retrieved from: https://www.kyoai.ac.jp/college/ronshuu/no10/onozawa2.pdf

OXFORD, R. L. (1990), Language learning strategies: What every teacher should know, Boston: Heinle \& Heinle Press.

PASAND, P.G., HAGHI, E.B. (2013), "Process-product approach to writing: the effect of Model Essays on EFL Learners' writing Accuracy”, International Journal of Applied Linguistics \& English Literature, 2 (1), 75-79. doi: http://dx.doi.org/10.7575/ijalel.v.2n.1p.75

PETRIC, B., \& CZARL, B. (2003), "Validating a writing strategy questionnaire", Procedia-Social and Behavioral Sciences, 31(2003), 187-215. doi:10.1016/S0346-251X(03)00020-4

ROSS, S. \& MORRISON, G. (2003), Experimental research methods, Retrieved from:

https://www.researchgate.net/publication/201382131_Experimental_Re search_Methods [accessed Jul 21 2021].

RAIMES, A. (1985), "What unskilled ESL students do as they write: A classroom study of composing”, TESOL Quarterly, 19 (2), 229-258.doi: $10.2307 / 3586828$

REFUGIO, C. (2018), Empirical research on Mann-Whitney U-test. Retrieved from:

https://www.researchgate.net/publication/329697950_Empirical_Resear ch_on_MannWhitney_test

REID, J. (2001), Teaching ESL writing, Upper Saddle River, NJ: Heinle and Heinle Press.

RUBIN, J. (1987), Learner strategies: Theoretical assumptions, research history and typology, In A. Wenden \& Joan Rubin (Eds.). 
SAVILLE-TROIKE, M. (2006), Introducing second language acquisition, Cambridge University Press: Cambridge.

SMET, M.J.R., BRAND-GRUWEL, S., LEIJTEN, M. \& KIRSCHNER, P.A. (2014), "Writing argumentative texts: The effects of electronic outlining on students' writing product and process: Sociocultural theory in writing strategies application", Procedia - Social and Behavioral Sciences, 98(6), 557-554. doi: 10.1111/j.1365-2729.2011.00418.x

SNOW, R. E., CORNO, L., \& JACKSON, D. N. (1996), "Individual differences in affective and conative functions", In D. Berliner (R. Calfee (Eds.), Handbook of educational psychology (pp. 243-310), New York: Macmillan.

YOUNG, D. J., \& OXFORD, R. L. (1997), "A gender-related analysis of strategies used to process written input in the native language and a foreign language", Applied Language Learning 8(2), 1-20. Retrieved from https://eric.ed.gov/?id=EJ552194

WATCHARAPUNYAWONG, S., \& USAHA, S. (2013), "Thai EFL students' writing in different text type: Theinterference of the first language", English Language Teaching, 6(1), 67-78. doi:10.5539/elt.v6n1p67

WENDEN, A. L. (1991), "Metacognitive strategies in L2 Writing: A case for task knowledge", In J. E. Alatis (Ed.), Georgetown University Round Table on Languages and Linguistics 1991 (pp. 302-322), Washington, D. C.: Georgetown University Press.

WISCHGOLL, A. (2017), "Improving undergraduates' and postgraduates' academic writing skills with strategy training and feedback", Frontiers in Education, 2(33),1 5-30. doi: 10.3389/feduc.2017.00033

ZAMEL, V. (1987), "Recent research on writing pedagogy", TESOL Quarterly, 21(4), 697- 715.doi: $10.2307 / 3586990$

ZEN, D. (2005), Teaching ESL/EFL writing beyond language skills: Affiliation, Southeast Missouri State University. Publication: Paper presented at the 3rd International Annual, Tonguha, China. 